\title{
Public Administration and Corporate Social Responsibility: How the State Can Promote Better Social Bonds
}

\author{
Administração Pública e Responsabilidade Social Empresarial: Como o Estado pode promover uma melhor \\ coesão social?
}

Abstract

As already formulated in Agenda 21 in Rio de Janeiro in 1992, the development of an inclusive municipality demands joint actions by citizens, social organizations, politicians, public administration and enterprises. This paper describes the experience of the municipal administration of Rottenburg am Neckar, Germany, to promote Corporate Social Responsibility (CSR). After a short presentation of the debate on CSR, it shows how to create a win-win situation with business-social partnerships. The paper illustrates how public administration can and should play an active role in creating, managing and coordinating CSR projects and makes suggestions on how to implement such projects at the local level in Brazil or elsewhere. The success of such a venture relies, among others, on professional project management with both financial and political support, and a strong and participating civil society.

Keywords: Corporate Social Responsibility, Public Administration, Civil Society, Social Projects, Management.

Daniela Theuer - daniela.theuer@gmail.com

Graduação com mestrado na área de Ciência da informação, complementada com Sociologia e Administração de Empresas, Universidade Livre de Berlim. Doutora em Ciência Política pela Universidade de Tübingen, Alemanha. Professora do Centro de Engenharia, Modelagem e Ciências Aplicadas (CECS) da Universidade Federal do ABC, área de Economia.

Artigo submetido no dia 22.02.2013 e aprovado em 18.11.2013

\section{Resumo}

Como já estabelecido na Agenda 21 da conferência Eco-92, no Rio de Janeiro, a criação de municípios inclusivos requer ações conjuntas e coordenadas entre cidadãos, organizacốes sociais, politicos, Administração Pública e empresas. Este artigo apresenta a experiência da Administração Pública da cidade de Rotténburg am Neckar, na Alemanha, em promover a Responsabilidade Social Empresarial (RSE). Após uma breve introdução sobre o debate em torno da RSE, demonstra-se como é possivel criar uma situação favorável para ambas as partes com parcerias empresariais-sociais. O artigo mostra como a Administração Pública pode e deve ter um papel ativo em criar, administrar e coordenar projetos de RSE. Ao longo do texto, apresentam-se sugestões de como implementar projetos dessa natureza na prática em municípıos, seja no Brasil ou em outras localidades. O sucesso depende, entre outros fatores de uma gestão profissionalizada com apoio político e financeiro, assim como de uma sociedade civil fortalecida e participativa.

Palavras-chave: Responsabilidade Social Empresarial, Administração Pública, Sociedade Civil, Projetos Sociais, Gestão Pública. 


\section{Introduction}

In the past 20 years, the debate about sustainable development and wider democratic participation led to several discussions on the proceedings to achieve that goal both in theoretical analysis and in practical politics. The demand for more participation and the increasing awareness of the mutual dependence of economic, social and environmental problems led to new perspectives on social responsibility. Led by the motto, "think global, act local;" Agenda 21, enacted in 1992 in Rio de Janeiro, demanded that:

each local authority should enter into a dialogue with its citizens, local organizations and private enterprises and adopt 'a local Agenda 21 (Chapter 28.3, UN 1992).

This put a new frame to city development initiatives. City development plans, formerly developed by politicians or technical experts with low or no, sometimes opposing citizen participation, should now be discussed with citizens and other social and economic actors.

In the city of Rottenburg am Neckar', Germany, the City Development Plan "step 2010", initiated in 1996, contained a passage affirming that all public functions should be adapted to the requirements of a social and ecological line of action, and that citizen participation for sustainable development at a local and global level would be promoted (LOKALE AGENDA 21, 2006: 12). In 1999, a local Agenda 21 was created with the participation of some parts of civil society. Four topics formed the general frame of action: culture, ecology, economy, and social issues (ibid.: 15). Various projects of the agenda were started and completed since 1999 in this small municipality of the State of Baden-
Württemberg (approx. 43,000 inhabitants) with a large number of associations and small business.

In 2005, the State Administration of Baden-Württemberg, initiated a pioneering project with the aim to promote Corporate Social Responsibility (CSR) by the public administration ${ }^{2}$. For that purpose, three regions and two cities got financial and organizational support to implement the idea. One of them was the city of Rottenburg am Neckar.

The Ministry for Work and Social Issues of the State of Baden-Württemberg supported the CSR Project. The Foundation of the State of Baden-Württemberg financed the state's project for the local promotion of CSR in three regions and two cities for three years, from 2005 to 2008. The Ministry organized regular meetings where project coordinators of regions and cities came together to report what they had done and which were the next steps. Later on, in 2007, an event was organized to present the projects and a final report (UBE 2008) conceptualized as a handbook of CSR promotion was presented by the Minister in 2009.

\section{Corporate Social Responsibility and Corporate Citizenship}

Before presenting the case of Rottenburg and how its results can be achieved by other cities, let's have a look at the origins and definitions of what we are talking about: CSR (Corporate Social Responsibility and CC (Corporate Citizenship).

Although a notion of "social responsibility" was already implemented by some businesspeople in the beginning of the 20th century in a practical way, the term "Corporate Social Responsibility" was first used by Bowen, who 
published a book on "Social Responsibilities of the Businessmen" in 1953 (BASSEN; JASTRAM; MEYER, 2003: 231). Two decades later, Carroll (1979, cited in MATTEN; CRANE 2003) developed a CSR model based on four types of corporate responsibility: (1) the economic responsibility to be profitable; (2) the legal responsibility to abide by the laws of the respective society; (3) the ethical responsibility to do what is right, just and fair; and (4) the philanthropic responsibility to contribute to various kinds of social, educational, recreational or cultural purposes. After the Brundtland Report (UN 1987), the UN Conference on Environment and Development (Rio 1992), and with increasing debates on ethics in business, the CSR concept was linked to the concept of sustainable development and defined as follows by the World Business Council for Sustainable Development (WBCSD) (ibid: 232):

Corporate social responsibility is the commitment of business to contribute to sustainable economic development, working with employees, their families, the local community and society at large to improve their quality of life (WBCSD 2000: 10).

The European Commission adopted a similar definition in 2001, regarding CSR as a concept that serves as a volunteer to companies to integrate social and environmental concerns in their business and in relation to their stakeholders (ibid.). Social Responsibility indices were adopted by Dow Jones (in 1999) and Bovespa (in 2005) to address an increasing interest of investors in "sustainable" business. In Brazil, the concept of CSR was largely spread by Instituto Ethos, a business association with the mission to:

mobilize, encourage and help enterprises to manage their business in a social responsible way, to make them partners in the construction of a sustainable and just society ${ }^{3}$.

The institute defines CSR as:

(...) way of managing defined by the ethic and transparent relation of the enterprise with all kinds of publics, and by the establishment of business goals which promote sustainable development of society, preserving environmental and cultural resources for future generations, respecting diversity and promoting the reduction of social inequalities ${ }^{4}$.

CSR, however, was not uncontested. Milton Friedmann, in his well-known article of 1970, criticized the concept as "pure and unadulterated socialism" (FRIEDMANN, 1970). For him, it undermined the core of a free market society, and as a radical liberal economist, he had already called it a "fundamentally subversive doctrine" in his book Capitalism and Freedom (1962). Friedmann's two main critiques were (1) the assumption in CSR that political mechanisms, and not market mechanisms, are the appropriate way to determine the allocation of scarce resources and (2) the appointment of corporate executives to act politically like civil servants, but simultaneously as legislators, executives and jurists, without being democratically elected.

Even if one does not agree with his basic individualistic and anti-governmentintervention views, Friedmann had a point: With which legitimation would companies decide who should get the money? He also rejected the implicit concept of "corporate" responsibility: in Friedmann's view, only 
individuals (spending their own money) could be socially responsible.

Carroll's CSR model neutralizes parts of Friedmann's critique. Certainly, the latter would not object to (1) the economic responsibility of a corporation to be profitable and (2) the legal responsibility to abide by the laws of the respective society. But he would certainly question (3) the ethical responsibility to do what is right, just and fair and (4) the philanthropic responsibility to contribute to various kinds of social, educational, recreational or cultural purposes as a corporation's, and not an individual's task.

Besides CSR, another term used to describe the idea of social responsibility is Corporate Citizenship (CC). In fact, CC is sometimes used as part of CSR or as its synonym. Both concepts are problematic, as Matten and Crane (2003) point out. They try to conceptualize what could be a corporate "citizen" drawing on the citizenship aspects categorized by T. H. Marshall (1965) (civil rights, social rights and political rights). Besides the question of whether a concept based on citizen rights is applicable to enterprises, the authors do not develop a normative concept of $\mathrm{CC}$, but restrict their discussion to a descriptive level of what enterprises are doing (if in a volunteer form or as reaction to societal pressure).

In Germany, CC is mostly used as a synonym to CSR. Due to the problems of the Corporate Citizen concept, I will use the term CSR to refer to socially responsible actions by enterprises, using it in the sense of Carroll's third (the responsibility to do what is right, just and fair) and especially fourth aspect (the responsibility to contribute to various kinds of social, educational, recreational or cultural purposes). To the fourth aspect, one should add the environmental aspect, although it was not a central issue of the study case presented below. The study case refers mostly to small and medium enterprises managed by their owners, and therefore, in this case, corporate responsibility is closely linked to the individual responsibility assumed by these businesspeople.

\section{The Case of Rottenburg am Neckar}

In the context of the action framework of the former "step 2010" and the demands of the local Agenda 21 to promote citizen participation, the position of a Coordinator of "Bürgerschaftliches Engagement", that could be translated as "Citizen Social Commitment", or "Public Service", had already been created in Rottenburg in 2001. The coordinator reported directly to the city mayor. The promotion of citizen and corporate social commitment was a strategy developed by the local public administration in cooperation with the city council. The aims (according to the description of the coordinator's duties) were:

- acknowledgement of what was being done,

- more participation,

- qualification and self-organization of civil society, to be achieved by public coordination, and

- project development with local partners.

In 2005, the Ministry's new CSR Project became part of the Public ServiceCoordinator's duties and started in the city. Financially and ideologically assisted by the municipal and the state administration, the Coordinator of Public Service of Rottenburg could develop new projects to foster CSR with the help of various interested and active people from 
local business and social organizations. He could also hire a project consultant to support the project ${ }^{5}$. Together, they formed what I will call here "Project Management".

The CSR project became a brand called UnterBürgern, a word that was composed of Unternehmen (enterprises) and Bürger (citizens), but could also be read as "among citizens". It got its own homepage (www. unterbuergern. $\mathrm{de}^{6}$ ) and its own label of people in a little boat, symbolizing that, in society, everyone is "in the same boat".

Embedded in the local Agenda 21, the city had already made a cultural-artistic project with youths in 2005, where local artists and youths created "art-points" on a trail to the city. The contacts of that project and other existing projects, like the "Garbage Clearing Project", in which students helped to clean the city center once a year, sponsored by local enterprises, were used to develop new projects, that should directly involve local enterprises.

\subsection{First Subproject and Proceedings}

One of the first projects implemented was one-week practical social training for business trainees called "Sozialpraktikum" (social internship). Participating enterprises (e.g. a bank) sent interested trainees into social organizations (e.g. kindergarten, home for elderly) for one week, continuing to pay them normally for their work. For the UnterBürgern Project Management (PM), the aim of such an initiative was not only business' social commitment, but also overcoming obstacles and prejudices between the different sectors, creating a platform of mutual understanding and deepening the sensation of "being in the same boat" with the common goal of socially sustainable development in the municipality.
Starting with this subproject, city administration organized an initial event inviting enterprises, social organizations and other local players explaining the aims of the local CSR Project, UnterBürgern. The existing subprojects were presented, as was the project's label with its own $\mathrm{Cl}$ (corporate identity) and a newly designed homepage. From that starting point on, a range of multipliers received information about the project.

The Public Service Coordinator formed a planning group (PG) with persons from local business interested in city development ideas. A new subproject, based upon an idea by a local businessperson, soon started: Business in School. It consisted of a schoolenterprises partnership, where teachers invited businesspeople to present practical aspects of mathematics, economy, etc. in class, and inform students on perspectives in the job market. The contact between businesspersons and teachers led to other ideas, like inviting enterprises to present their business at an open day in school. Thus, students could see which capabilities were necessary in the region they lived, and this could help them decide which profession they could choose.

To plan further projects, a written survey on CSR was sent to all local enterprises. A return of $10 \%$ (85 answers) showed that $95 \%$ of the responding enterprises were already involved in social projects, mainly through donations or sponsoring, but only $11 \%$ of them used that commitment in public relations. Most of the enterprises were small ones, with up to 10 people working in them. Thirty-five percent showed interest in publishing their social responsibility actions 
on the new UnterBürgern homepage.

The homepage became a central platform to inform all citizens about news related to the projects. One section offered socially committed enterprises the possibility to describe their social actions. There were also reports of events, links to related homepages, the description of projects and all press articles referring to UnterBürgern. Active public relations work was part of the CSR Project's open information and transparency policy. Reports on events in the local press also helped to make the project better known in the region.

Based on the information on existing commitments, Project Management sought a new way to bring business and social organizations together. The "Marketplace" method, coming from the Netherlands and diffused in Germany by the Bertelsmann Foundation (see, for instance, BERTELSMANN STIFTUNG, 2007), was elected as a means to deepen CSR in Rottenburg.

\subsection{The Marketplace-Method}

The "Marketplace" is an event to bring business and local organizations together in a short period (e.g. two hours), to negotiate shortor long-time projects and partnerships. In a more or less informal atmosphere, mixed with some formal aspects, social organizations can search for project partners. It is important to remark that social organizations do not negotiate as beggars, but as equal partners that give something in return, as not only fundamental players and part of societal infrastructure for everyone, including local entrepreneurs, but also in the partnership itself. Thus, several preparation steps were taken.

First, a qualifying workshop for local social players was organized. An external agency as well as local businesspeople demonstrated how businesspeople think, act and what their expectations are in relation to social projects. On the other hand, members of social organizations could expose their needs and get help in formulating their projects. One of the main objectives of the workshop was to show there are more than just financial possibilities of social commitment and aid for projects and partnerships. Another aim was to show the value of social organizations for the community to all participants. A third aspect was a clear definition and communication of the social organization's demands.

Then, another written survey was sent to social organizations, to complete the information the Project Management had of what was being done in CSR and what the needs of those organizations were. They were requested to answer questions about existing business aid, projects, and in which areas they needed help according to five categories of the "Marketplace": (1) man/womanpower, (2) know-how, (3) specific donations, (4) media/ public relations, and (5) networking or others. They were also asked to specify their needs, as previous conversations showed that social organizations often communicate their needs in a rather diffuse way and lack professional management by objectives. The survey was also a way to inform people about the CSR Project and the "Marketplace", which was being organized.

The next step was the invitation and organization of separate informational evenings for interested businesspeople on 
the one hand and social organizations on the other. The functioning of the Marketplace was explained and so were the needs of local social organizations. The Planning Group (PG) contacted enterprises to join the Marketplace and had outstanding public persons to help at the event. These persons were asked to be "mediators" to help bring together businesspeople and members of social organizations, if needed.

On June 17, 2007, the Marketplace achieved a high participation of both businesspeople and social organizations (nearly 40 each), also attracting the attention of external guests. The event started with a choir from one of the city's primary schools and the opening words by the mayor. Soon, a buzz of conversations started, partnerships were settled quicker than they could be registered. One of the main rules of the Marketplace was not to talk about money. Projects should be settled in the five categories (1) man/womanpower, 2) know-how, 3) specific donations, 4) media/public relations, and 5) networking or others). The place in which the event took place was divided in accordance with these categories. Only when an agreement was reached could you ask the partners the cost in the free market, if bought.

The "contracts" were signed, copied twice and registered by members of the Planning Group helping to organize the event. They acted as "notaries", to underline the seriousness of the CSR project and added the money "value" of the agreements to announce it at the end of the event. Two copies were made of the project agreements between business and social organizations (or between social organizations), so one copy could remain with each partner, and one with Project Management. More than 80 co-operations were settled in less than one hour of negotiations. The central project overview and evaluation lied in the hands of CSRProject Management. That was important for the analysis and control of outcomes and for planning further Social Responsibility actions.

A second "Marketplace" took place in November 2008 and a third in April 2010. Since the city already knew what to do, the preparation work was much less extensive.

\subsection{Other Important Subprojects}

Meanwhile, UnterBürgern Project Management implemented other projects. One was the Job-Godfather-Project. The target group for this project was youths with poor chances to get a job or enter a training program. Interested businesspeople could accompany the young people, helping them with advice regarding application procedures, personal networking and possible job opportunities. UnterBürgern provided qualification units for the "godfathers" with experts on youth work, regular meetings to exchange experiences and organization of the network between "godfathers", teachers and social workers at participating schools.

Another crucial UnterBürgern project was the qualification of social players, especially volunteer workers. Rottenburg offered a qualification program in various areas of interest, such as working methods, legal issues, information on social offers and specific qualifications for running projects. ${ }^{7}$

\subsection{Results}

The results of the CSR Project were very positive. Its main results were the agreed-upon partnerships, the possibility 
of internships, of broadening skills, of getting help in a job search. Rottenburg am Neckar positioned itself as a model of social cohesion. Participants in the Project, local citizens and the local press mentioned the city and the CSR Project in a positive way. Externally, Rottenburg could present itself as a successful part of the State's pilot project on CSR incentives. As for the subprojects, each had different results:

\section{a) Social Internship}

It is not always possible to measure the effect of such programs in numbers, but feedback revealed that all participants won. The trainees experienced working in an organization with completely different aims than their own business. The enterprises hoped to get a long-run profit out of better soft (social) skills of their new employees, and social organizations had some help and learned that business-oriented people could also act socially.

\section{b) Marketplace-Method}

The Marketplace-Method turned out to be a very effective and efficient way to create new partnerships especially between business and social organizations. Although it needed careful and somewhat extensive preparation, the partnerships themselves were reached in one or two hours. The partnerships were designed in a way for both sides to contribute. This gave all the participants a feeling of getting help without being just beggars. Many small problems were solved in an uncomplicated way. The control of which were actually implemented was done by Project Management.

\section{c) Job-Godfather-Project}

The Job-Godfather-Project helped students learn more about their possibilities and better organize their lives concerning their aims. It brought together public administration, teachers, school directors, and people interested in helping. For the "godfathers" (and -mothers) it gave a feeling of contributing with something that is very basic but important. The project also helped people to get in contact with each other. The project also received support from a local organization for integration and professionalization, whose manager offered qualification courses for "godfathers".

\section{d) Qualification Program}

The Qualification Program offered courses of interest for people working in social organizations or associations. The program included courses on fiscal topics, managing time, special issues like how to deal with youths and others, and was free of charge. It helped people in the city develop their skills, and increase their contribution in their often volunteering work.

\section{Aspects of the City in the Study Case}

Rottenburg is a municipality with 43,000 inhabitants, located in the center of the state of Baden-Württemberg, in the southwest of Germany. The main city has approximately 22,000 inhabitants and 17 external districts that were former villages included to the municipality in the 1970s. It has a demographic density of 298 inhabitants per $\mathrm{km}^{2}$, in the mean of the state of Baden-Württemberg. The Neckar River crosses the municipality in an extension of $14.5 \mathrm{~km}$. 
Figure 1 - The city of Rottenburg am Neckar in Germany

\section{The city of Rottenburg am Neckar in Germany:}
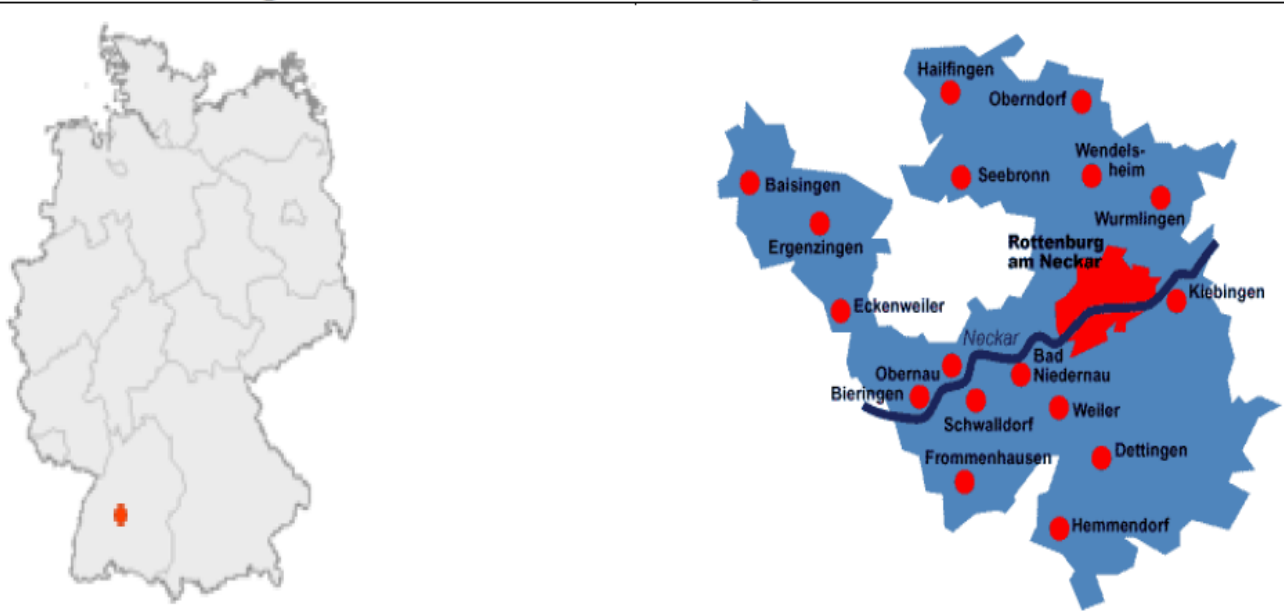

Source: www.rottenburg.de

The major part of the municipality's area of 14,226 ha is rural (54.3\%), and it has a huge part of forests $(29.3 \%)$. Only $14.5 \%$ (2.068 ha) are urban area. The Neckra River crosses the city.

Table 1: Area Usage in Rottenburg

\section{Area Usage in Rottenburg:}

\begin{tabular}{|l|l|l|}
\hline Urban area & 2,068 ha & $14.5 \%$ \\
\hline Rural area & 7,731 ha & $54,3 \%$ \\
\hline Forest & 4,173 ha & $29,3 \%$ \\
\hline Water area & 135 ha & $0.9 \%$ \\
\hline Other & 118 ha & $0.8 \%$ \\
\hline \multicolumn{2}{|l}{} \\
\hline
\end{tabular}


Rottenburg had an unemployment rate of $4.8 \%$ and 14,582 socially secured employed citizens in $2008 .^{8}$ There were 7,382 employees (with social security payments) working in the municipality, 3,338 of which come from other locations. Another 10,472 people living in Rottenburg worked outside the municipality. Since more people living in Rottenburg work outside than people from other regions work in the city, and the local income tax share is calculated on the working place and not the living place, there is minus 7,134 income tax payment revenues compared to the population and a need for infrastructure (social, health, educational, etc.). This is an important aspect of the city's financial income, as the main income of the municipality comes from the local share of income taxes, the trade tax, the real estate tax and other specific state allocations.

The business structure consisted of 20 industries, regional bank branches and more than 800 smalland micro enterprises (tradeand services). Rottenburg also has a widespread social, educational, cultural and health infrastructure, as can be seen in the table below:

Table 2 - Social, education, culture and health infraestructure of Rottenburg am Neckar

\begin{tabular}{|c|c|}
\hline \multicolumn{2}{|c|}{$\begin{array}{l}\text { Social, Education, Culture and Health Infrastructure of Rottenburg am Neckar } \\
(2008)\end{array}$} \\
\hline Kindergartens and Small-Child-Groups & 80 \\
\hline Primary Schools & 15 \\
\hline Secondary Schools & 10 \\
\hline Technical University (Forestry and Environment) & 1 \\
\hline Museums & 5 \\
\hline Civil society associations & 300 \\
\hline Sports infrastructures & 42 \\
\hline Hospital & 1 \\
\hline Physicians (general) & 23 \\
\hline Physicians (specialists) & 29 \\
\hline Dentists & 19 \\
\hline Homes for Elderly & 5 \\
\hline
\end{tabular}


The number of associations shows that civil society is well organized. Volunteer work is very common, especially membership in sports organizations. Rottenburg, with 300 civil society associations, reflects almost perfectly the huge German density of associations (7.1 per 1,000 inhabitants in $2011^{\circ}$ ). I will not deepen the discussion here on the importance of civil society organizations as "learning platforms" regarding political and social participation. Some aspects appear in Theuer 2011. In Rottenburg, some businesspeople are themselves members of such associations, so they know how part of the "social" universe "works". This was not true the other way round: normally, people working in the social area did not know how enterprises work. Another important aspect of Rottenburg was a political one: the mayor had broad support in society and in the local City Council.

\section{The CSR Approach by Public Administration: Success Factors}

This sectionanalyzessomeaspects of the criteria and background from promoting CSR by the public administration in Rottenburg am Neckar. It shows how local entrepreneurs were won over to act in favor of city development and presents some aspects of the project that were important for its success. I will divide them here into seven categories: (1) content, (2) management, (3) partners, (4) method, (5) communication, (6) political support and (7) society.

\section{1) Content's relevance}

In the first place, CSR itself and the subprojects addressed content visibly in demand and seen in a very positive way in society. The subprojects brought knowledge from one sector (enterprises) to the other (social). However, businesspeople also learned new things, like the "job-godfathers" who were qualified with knowledge in the social area. All subprojects addressed existing needs and were a bridge between theory and praxis.

\section{2) Professional Management}

Another important factor of success was the organization and management of the CSR Project. The Public Service Coordinator and the project consultant assisting him coordinated the subprojects, organized the meetings, written and visual communication, presented and explained the project, and so on. The professionalism of the CSR Project, revealed in wellprepared events with information based on relevant facts and professional layout of all published materials was very important for credibility and seriousness, especially by the businesspeople target group.

\section{3) Active Partners/Participation}

A third success factor was the way in which partners were included in the CSR Project. This refers to persons in the Planning Group as well as to how enterprises and social organizations were encouraged to participate. The Planning Group included already interested entrepreneurs of the city in the organization and caption of ideas. Their participation was crucial not only because of their ideas and because of their help in the organization, but also because they helped spread the idea of CSR and information on the CSR Project.

The enterprises included in the CSR project were mostly small and micro enterprises. Social Responsibility is already a big deal for huge, international enterprises, being part of criteria to classify them, but at the local level the aim is closely related to local development. Of course, huge enterprises from outside 
can also be persuaded to join local projects. In Rottenburg, (former) DaimlerChrysler (located in Stuttgart) sent 20 trainees to work for a week building a new school playground in one of the city districts. However, even in a small community with some local trade and industry there are lots of resources and often good will that just has to be employed correctly and just needs coordination to be transformed into concrete projects.

\section{4) Method}

In Rottenburg, UnterBürgern Project Management decided to begin with small projects and use the positive results as incentives to gain more supporters among local businesspeople. Surveys gathered information on what was already being done and what the actual needs were. Bigger events like the "Marketplace" were prepared, documented and supported. The CSR Project evolved in a continued learning process for all involved people, always open to suggestions and ideas.

\section{5) Communication and Transparency}

Another important success factor was the active and transparent communication of the project. Meetings of the Planning Group, course offerings, the search for "jobgodfathers" and so on, were announced in the local administration's printed newsletter, which is widely distributed in the city. Photos and videos accompanied the project. All information was published in the Project's homepage. Active public relations work made Rottenburg's CSR Project appear in the local newspaper. Meetings of subprojects were always registered and sent to all participants.

The CSR Project was presented in public events, and Project Management was involved in qualification workshop lectures on CSR.

\section{6) Political and financial support}

Rottenburg's CSR Project had double political support, which certainly was another factor of success. On one hand, it was part of the organization and support of the Ministry of Work and Social Issues of the State of BadenWürttemberg. Regular meetings were held, and each locality was financially supported by the state's foundation. On the other hand, inside the city, the project had the support of the mayor. That is a very important factor. It certainly makes a difference if the mayor is a respected public person (as in the case in Rottenburg, but unfortunately that is not the case everywhere) and invitations and bigger events count with his/her participation.

\section{7) Society}

The support of CSR actions in society is another very important success factor. Rottenburg already had a well-organized civil society. However, even then, people sometimes did not have the idea to ask businesspeople for help. With the CSR Project, local public administration offered a platform that was missing to bring people together. Creating an environment of recognition and the possibility of further participation with positive and visible results reinforces the sense of community as well as individual wellbeing, as reported by people acting in the project.

The Rottenburg case shows that Corporate Social Responsibility can be actively promoted by public administration. It is essential, though, to observe the factors listed above. Furthermore, there has to be a political will of the government to implement such a CSR project. In this case, local aspects have to be taken into account. 


\section{Brazil, Brazilian Cities and CSR}

In Brazil, CSR is getting more and more important as a topic. Institutions like IDIS (Instituto para o Desenvolvimento do Investimento Social) and Instituto Ethos are engaged in spreading the idea of social commitment by business. ${ }^{10}$ Organizations like IBASE (Instituto Brasileiro de Análises Sociais e Econômicas) and CEBDS (Conselho Empresarial Brasileiro para o Desenvolvimento Sustentável) show the responsibilities of economic agents from different perspectives of just development and sustainability. Many big companies have incorporated CSR in their business. Nonetheless, it is still not a strategic issue, and public administration has not yet played an active role concerning CSR.

\subsection{CSR in Brazil}

In abrochure published by the formerGerman development agency GTZ ${ }^{11}$ (Gesellschaft für Technische Zusammenarbeit), Brazil was classified as being in a "first generation" of CSR policies, with focus on civil society and politics (GTZ2007: 10). Table 1 below shows GTZ's findings in comparative perspective.

Table 3 - CSR in Brazil and other countries, comparative perspective

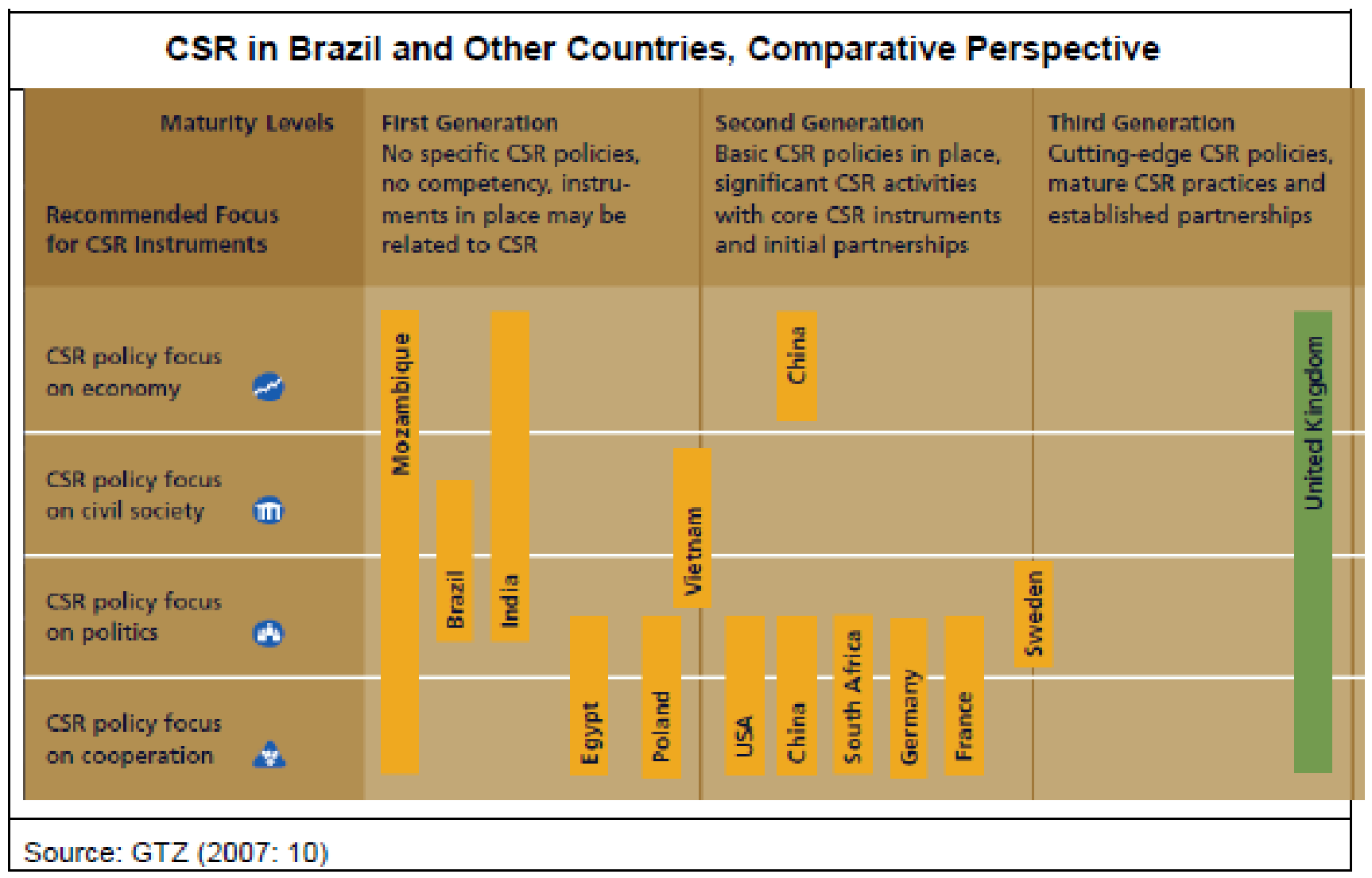


The report on Brazil, made in cooperation with IDIS, states that CSR in Brazil "remains largely driven by the business community" (GTZ 2007:12). Further, it affirms that:

"[t]he public sector addresses CSR only sporadically and there is no coherent formulation of a CSR strategy on the part of the government. Furthermore, there is neither a visible contact point within government nor a public coordination point for CSR." (ibid.:13)

The business-led promotion of CSR in Brazil is reflected in the literature on CSR, which focuses primarily on CSR in enterprises, and normally big ones. For micro and small enterprises, SEBRAE (Serviço Brasileiro de Apoio às Micro e Pequenas Empresas) and Instituto Ethos launched a "guide" in 2003 (SEBRAE/Ethos 2003). However, even when the state or municipalities are briefly mentioned, like in a UN Report of 2004 (CAPPELLIN; GIULIANI, 2004), the state is mentioned only as a provider of legal frameworks or fiscal incentives, not as an active player in fostering CSR.

Examples of using the legal framework in Brazil for achieving social and environmental development aims are changes in the Public Procurement Law (Lei de Licitações) in 2010 and other decrees. This includes sustainable development as an objective of state purchases, including the hiring of cooperatives or small local producers; quota laws, the law concerning national policies to deal with climate change, which proposes integration and responsibilities of different sectors of society.

This kind of legal framework shows how Brazilian government is concerned with social and environmental issues. Development is defined in a broader way than only economic growth. On the other hand, regarding social responsibilities, it is primarily focused on the state itself as economic agent and development fosterer. Corporate Social Responsibility continues being a voluntary act. Assumpção and others (Assumpção et al. 2008) made an effort to analyze Brazilian business CSR on an aggregated level, in what is called the "S-System". This system comprises business associations like SESI, SESC, SENAI, and so on ${ }^{12}$, which provide important parts of social services (in leisure, education, material assistance, etc.) in Brazil, and therefore are a special form of CSR. They describe the historical background and the connection to state and developmental initiatives. In this sense, the Brazilian state fostered CSR is more than acknowledged in current international literature.

This paper focuses on the possibilities of local administrations. In Brazil, the S-System may be a good partner when a government decides to foster CSR in its region.

\subsection{The reality of Brazilian Cities}

The Brazilian Federal Constitution (FC) of 1988 included citizen participation as one major aim of democracy. Councils with the participation of government, public servants and citizens should be and were created to meet this demand of participation. Some municipalities, like Porto Alegre, implemented the participatory budgeting method, in which citizens could express their investment preferences for the city (for an analysis of its success see Theuer, 2011). On the legal side, states and municipalities were to implement local laws that would be the framework for action in each locality. Often, those framework 
acts (leis Orgânicas Municipais-LOAs) included and reinforced the idea of citizen participation in politics. The FC of 1988 also increased tax transfers to municipalities, giving them a larger margin for investments. On the other hand, part of the investments were earmarked for specific areas (health, education), and the new possibilities of making investments with credits (increasing municipal debts) were restricted with the law of fiscal responsibility (Lei de Responsabilidade Fiscal, LRF) of 2000.

From 1940 to 2010, the number of Brazilian municipalities increased from 1,574 to 5,565 (IBGE 2010: 3). Forty-five percent $(2,513)$ have fewer than 10,000 inhabitants, and another $44 \%(2,444)$ have from 10,000 to 50,000 inhabitants. Thus, almost $90 \%$ of Brazilian cities (4,957 or $89 \%$ ) have fewer than 50,000 inhabitants, and are the social environment for $33.5 \%$ of all Brazilians (ibid.).

Today, there is a huge concurrence between states and between cities to attract enterprises to their region. This is reflected in a "run" of tax incentives, free service provisions by the state, donation of land and so on. The expected counterparts are employment of local citizens and direct and indirect future tax returns. This article proposes that enterprises can do more than that for the place in which they earn their profit. But the essential partners for a CSR conceptualized as part of a local development strategy, as suggested here, are the small and medium enterprises.

\section{How Local Public Administrations can Promote CSR}

Although there are cultural, organizational and structural differences between a city like Rottenburg am Neckar, in Germany, and other cities in the world, the CSR Project can be adapted to other local realities in which we find local enterprises that are already running stable in their business. Local administrations can start their own project, observing the success factors mentioned above, and adapting them to their own local political and social reality. The success factors mentioned above for the case of Rottenburg can serve as a guide for implementing a CSR Project by the local administration. This means that all seven factors (1) content, (2) management, (3) partners, (4) method, (5) communication, (6) political support and (7) society should be observed.

\section{1) Content's relevance}

If CSR is not yet a topic in the city, public administration can push it. If it is already a topic or a demand, this can be used as a base to develop projects that are really needed. The first important step is getting to know if and how CSR is already being done in the city. Therefore, the first step to be made is a survey. How this survey is made depends on the city's reality: it can start with meetings or dialogues with entrepreneurs and members of social organizations, or be a written survey, or both. Getting in touch with the CSR partners, explaining the advantages of the Project to all involved partners and to local society is of utmost importance.

\section{2) Professional Management}

Define who will be responsible for the CSR Project. If appropriate, a consultant can be asked to assist the process. It is important to define tasks and responsibilities if there is more than one person responsible. Meetings should be well-organized and the whole process documented. 


\section{3) Active Partners/Participation}

Even being an active player in the CSR Project, public administration should not act on its own. The more people participate in the process, the more they identify with the cause. Thus, interested businesspeople and members of social organizations should be involved from the beginning.

\section{4) Method}

The initial survey is, of course, one of the methods that can be used to know where to start. There is no ready-made formula on which method is the best in each case. However, starting with one subproject and then expanding the project, instead of doing too many things at the same time, was a successful path in the case presented.

\section{5) Communication and Transparency}

An active public relations policy is needed for the project to succeed. Press releases should be sent to the local press, and permanent updating of the homepage as the main information platform to the public is fundamental. Also, it is important to remark that planning and project meetings should be open to the public and published in the local press. People should have the possibility to requestreports and meeting minutes to Project Management as part of a transparency policy.

\section{6) Political and financial support}

A CSR Project fostered by public administration has to have political support. In the best case, not only the mayor, but also local assemblypersons should back the idea. And, of course, the project will need financial resources (besides human resource costs) to flourish: to get professional assistance in the organization, to make the events, to communicate (e.g. letters and homepage), to make a campaign for the project, to document it on video, etc.

\section{7) Society}

As mentioned, even if CSR is a new topic, a civil society that is already well organized and knows the importance of social participation will support it and value the results. Of course it is all a learning process, and CSR may be used as a means to make people get more involved with social (and political) issues.

Summarizing, the success of any CSR Project lies in:

- Getting to know what is already being done;

- Getting to know what should be done;

- Starting with actual needs;

- Having a professional management;

- Being well-organized;

- Asking for suggestions;

- Involving people of different sectors (business, social organizations, civil society associations) in the process;

- Having a good and active communication;

- Having political and financial support;

- Having an interested and organized civil society (or to stimulate organization and participation);

- Creating an atmosphere of recognition of CSR;

- Being open-minded to learn from others.

\section{Final Remarks}

Local administration's action largely depends on the political project of elected representatives and on the scope given by formal rules and financial funds that can be invested. The income tax share of municipalities in Germany, for instance, is redistributed according to the place of work, and not the living place of the employees. At the same time, the living place is where 
the whole social, educational, and health infrastructure has to be offered. This is one of various points that being discussed at the state and union level, as the legal regulation of tax sharing is decided there. In Brazil, similar discussions are to be expected.

With several service obligations and relatively little direct influence on financial incomes, municipalities have to use the scope they have and try to attract enterprises and highqualified, correspondingly high income, work places. In a post-modern, increasingly hightechnology and service-oriented society, an attractive social environment becomes a location factor for enterprises and citizens, and can be achieved by sustainable development policies. Regarding this kind of development just as economically relevant, however, can be dangerous: citizens are always concerned that the state, in this case the local public administration, could have an interest to stimulate business-social partnerships to release itself from investments in social issues. In a country like Germany, where people expect the welfare state to do its part to ensure a high quality of life, this is a difficult tightrope walk.

The experience of Rottenburg am Neckar demonstrates that good, professional preparation is a necessary success factor for the CSR Project, even in a small/medium community with a strong and organized civil society. Social players and business are still completely alien spheres to each other, especially the business world for social players. One of the important aims of coordination is networking and overcoming prejudices. There are lots of barriers to be overcome, but also lots of resources that can be mobilized for local, social sustainable development.

The widespread image of exclusively egoistic, self-constrained and just profit-oriented businesspeople does not fit with this local experience, where enterprises are mainly small sized. Certainly, there is always a smaller group willing to act according to social values, whereas a great part continues doing business as usual. Participation in decision processes is essential to results. Therefore, an already socially oriented group of businesspeople should be directly integrated into the decision processes. This may be a qualitative benchmark for local "good business" and good social partnerships, as well as for "good government." Businesspeople, social organizations, interested citizens may start new projects along with public administration.

In Brazil, CSR is a topic still in its first steps. Instituto Ethos, founded in 1998, has already done a good job in spreading the concept inside enterprises. The inclusion of CSR in local development strategies could be the next step, as cities are already implementing sustainability policies and participative politics. In this sense, new concepts of social contracts are emerging (see also THEUER, 2009). Also, the role of the state is being redefined. In the case presented, the state (and especially government) plays an active role in creating possibilities of interaction for the members of society. All the same, the state continues to provide essential social security and services.

Ultimately, CSR is a kind of in-depth citizen participation, while the participating citizens continue to occupy certain roles. Enterprises participate either through their owner or as players of their own. No enterprise will adopt CSR strategies if there is no consensus to do it, whether as a result of philanthropy by a majority of 
owners, or of getting more profits because consumers are changing their values. Most interestingly, the opposition which CSR encounters comes as well from liberals as from socialists. Liberals, like Friedmann, reject the "socialist" aspect in it, whereas socialists fear the ultimate stabilization of the capitalist system with its problems of power and income distribution. Indeed, CSR, like other participating methods, could be used to disguise problems without really solving them. On the other hand, they can be used as a means to solve real existing problems with the available resources and to integrate society using common sense.

\section{References}

Assumpção, M./ Moisés, J. A./ Sacchet, T./ Trygstad, S. (2008): CSR in two countries: Brazil and Norway. Fafo-Report 2008:10

Bassen, A./ Jastram, S./ Meyer, K. (2005): Corporate Social Responsibility. Eine Begrifsserläuterung. zfwu 6/2 (2005), 231236

Bertelsmann Stiftung (2007): Gute Geschäfte. Marktplatz für Unternehmen und Gemeinnützige. Leitfaden. Brochure. Bertelsmann Stiftung, 2007

Cappelin,P./ Giuliani, G. M. (2004): The Political Economy of Corporate Responsibility in Brazil. United Nations Rsearch Institute for Social development, Technology, Business and Society Programme Paper Number 14, October 2004

Carroll, A. B. (1979): A Three Dimensional Model of Corporate Social Performance. Academy of Management Review, 4: 497505.
Europäische Kommission (2001): Europäische Rahmenbedingungen für die soziale Verantwortung der Unternehmen. Grünbuch, Luxemburg: Amt für amtliche Veröffentlichungen der Europäischen Gemeinschaften, COM (2001) 336 final, Brüssel.

Friedmann, M. (1970): The Social Responsibility of Business is to Increase its Profits. The New York Times Magazine, September 13th, 1970

Friedmann, M. (1962): Capitalism and Freedom. Chicago: University of Chicago Press

GTZ (2007): The CSR Navigator. Public Policies in Africa, the Americas, Asia and Europe. Brochure. Bertelsmann Stiftung/GTZ, 2007

IBGE (2010): Censo Demográfico 2010. Sinopse do Censo e Resultados Preliminares do Universo. Rio de Janeiro: IBGE

Lokale Agenda 21 (2006): Lokale Agenda 21: 1999-2005. Brochure. Stadt Rottenburg am Neckar, Baudezernat/Geschäftsstelle der Lokalen Agenda 21, März 2006

Marshall, T. H. (1965): Class, Citizenship and Social Development. New York: Anchor Books

Matten, D./ Crane, A. (2003): Corporate Citizenship:Towards an ExtendedTheoretical Conceptualization. ICCSR Research Paper Series, No. 04-2003

Oliveira, I. C. E. de (2001): Estatuto da Cidade: para compreender... Brochure. Rio 
de Janeiro: IBAM/DUMA, 2001

Puppim de Oliveira, J. A. (2008): Empresas na Sociedade: Sustentabilidade e Responsabilidade Social. Rio de Janeiro: Elsevier

SEBRAE/ Instituto Ethos (2003): Responsabilidade Social Empresarial para Micro e Pequenas Empresas: Passo a Passo. Brochure. São Paulo, outubro de 2003

Theuer, D. (2009): Democratic Participation and the Management of Scarce Resources. The Convergence of Leftist and Neoliberal Approaches in Times of Discontent with the Social Contract. Temas de Administração Pública, online, UNESP, Araraquara, Vol. 4, No. 5

Theuer, D. (2011): Der Partizipative Haushalt und der Wandel, der inn trägt. Hintergründe, Akteure, theoretische Konzepte. Universität Tübingen, Diss. Tübingen: Tobias-Lib

UBE (2008): Unternehmerisches Bürgerschaftliches Engagement fördern. Ein Handbuch für die Praxis. Brochure. Ministerium für Arbeit und Soziales, Baden-Württemberg, $12 / 2008$

UN (1992): United Nations Conference on Environment \& Development. Rio de Janeiro, Brazil, 3 to 14 June 1992. Agenda 21. http://www. un.org/esa/sustdev/documents/agenda21/ english/Agenda21.pdf

UN (1987): Our Common Future: The World Commission on Environment and Development, United Nations, New York, 1987 (also known as the Brundtland-Report)

\section{Notes}

1. I will sometimes abbreviate the city's name to Rottenburg in the text to simplify reading.

2. At the Ministry, the two terms generally used to denominate the project were CC (Corporate Citizenship) and UBE (Unternehmerisches Bürgerschaftliches Engagement), the German translation of CSR (Corporate Social Responsibility).

3. www.ethos.org.br, own translation.

4. Own translation. In the original: "Responsabilidade social empresarial é a forma de gestão que se define pela relação ética e transparente da empresa com todos os públicos com os quais ela se relaciona e pelo estabelecimento de metas empresariais que impulsionem o desenvolvimento sustentável da sociedade, preservando recursos ambientais e culturais para as gerações futuras, respeitando a diversidade e promovendo a redução das desigualdades sociais." (source: http:// www1.ethos.org.br/EthosWeb/pt/29/o_ que_e_rse/o_que_e_rse.aspx)

5. The CSR project of Rottenburg am Neckar was supported by the author.

6. The homepage is still online, but only in German.

7. Two more subprojects, an internship which enterprises offered to people, especially youths, with intellectual disabilities, and a project for better integration of immigrants that started after the described period, were part of the CSR project, but they were not accompanied by the author.

8. Data of the homepage of the city of Rottenburg am Neckar, www.rottenburg.de.

9. Source: http://www.registeronline.de/ vereinsstatistik/2011/, based on data of the German Federal Statistics Public Administration and CSR p. 26/26 Department (Statistisches Bundesamt).

10. IDIS (Instituto para o Desenvolvimento do 
Investimento Social) is a small organization which promotes CSR more in a philantropical way. Instituto Ethos is a business association that spreads the concept of CSR as part of business strategy.

11. Former development agencies GTZ DED (Deutscher Entwicklungsdienst) and Inwent merged to form the new German development aid agency GIZ (Deutsche Gesellschaft für internationale Zusammenarbeit $\mathrm{GmbH}$ ) in 2011.

12. The authors include 9 organizations in the S-System: Serviço Social do Comércio (SESC), Social Commerce Services); Serviço Nacional de Aprendizagem do Comércio (SENAC), National System for Commercial Training;
Serviço Social da Indústria (SESI), Industry Social Services; Serviço Nacional de Aprendizagem Industrial (SENAI), National System for Industrial Training; Serviço Social do Transporte (SEST), Transport Social Services; Serviço Nacional de Apoio ao Transporte (SENAT), National Transport Support Service; Serviço de Aprendizagem Rural (SENAR), Rural Training Service; Serviço Brasileiro de Apoio às Pequenas e Médias Empresas(SEBRAE), BrazilianSmalland Medium Size Businesses Support Service; Serviço Nacional de Aprendizagem do Cooperativismo (SESCOOP), National Cooperativism Training Service (ASSUMPÇÃO et al., 2008:37). 